\title{
Numerical and Theoretical Study on the Settlement of Capped Piles Composite Foundation under Embankment
}

\author{
Ming-Quan Liu, ${ }^{1,2,3}$ Da Huang $\mathbb{D}^{1},{ }^{1}$ Yi-Xiang Song, ${ }^{1}$ and Duo-Feng Cen ${ }^{1}$ \\ ${ }^{1}$ School of Civil and Transportation Engineering, Hebei University of Technology, Tianjin 300401, China \\ ${ }^{2}$ School of Civil Engineering, Tangshan University, Hebei 063000, China \\ ${ }^{3}$ Hebei Key Laboratory of Building Engineering and Tailings Utilization, Tangshan 063000, China
}

Correspondence should be addressed to Da Huang; dahuang@hebut.edu.cn

Received 18 December 2019; Revised 27 June 2020; Accepted 19 July 2020; Published 18 August 2020

Academic Editor: Pier Paolo Rossi

Copyright (c) 2020 Ming-Quan Liu et al. This is an open access article distributed under the Creative Commons Attribution License, which permits unrestricted use, distribution, and reproduction in any medium, provided the original work is properly cited.

\begin{abstract}
Capped piles are efficient in settlement control and have been widely used in the reinforcement of soft soil foundations for highspeed railways and highways. In this study, scenarios involving both capped piles and ordinary piles without caps are numerically studied using the finite element software (ABAQUS). The settlement characteristics of capped piles composite foundation considering the effects of both the pile spacing and the ratio of pile cap to pile diameter are achieved. Based on the numerical results, assuming that the capped pile and the soil under the cap jointly bear load and settle together, a settlement calculation model for capped piles composite foundation is established. By both replacing the compression modulus with the deformation modulus obtained from the field static load test and calculating the area replacement ratio, the formula for calculating the total settlement of the capped piles composite foundation is derived using the layer-wise summation method. In addition, a real embankment engineering with capped piles composite foundation is adopted to validate the accuracy of this method; by comparing with other methods, the results show that this method is in better agreement with the field monitoring data. Therefore, the proposed method is recommended in the relevant engineering design.
\end{abstract}

\section{Introduction}

Capped pile is usually made up of a rigid pile body and a pile cap. The rigid pile body is mostly PHC or PTC in practice. The pile cap is usually a round or a square concrete slab, and the diameter or side length to pile diameter is $2 \sim 4$ [1]. In order to maintain sufficient rigidity, the thickness of pile cap is $200 \mathrm{~mm} \sim 500 \mathrm{~mm}$; the larger the load, the larger the thickness [2]. The pile cap reduces stress levels at the pile top, helping maintain the integrity of the overlying cushion [3]. For convenience, the rigid capped pile is referred to as the capped pile in following study.

Capped piles are frequently used in pile-supported embankments [4] or pile-net composite foundations [5]. Engineering experiences had shown that composite foundations with capped piles effectively reduced the settlement and the failure of embankments on soft soils [6-9], especially in highspeed railway and highway engineering [10, 11]. Many findings had been reported on bearing behavior, bearing mechanism, and the pile-soil stress ratio of capped piles [12-17]. Research methods include field tests [18], physical model tests [19-21], and numerical simulations [22-26]. Some theoretical studies that address settlement calculation in pile-supported foundations have been carried out. In particular, (1) if the load acting on the soil between the piles has been determined, the settlement can be calculated as the deformation of the soil between the piles [27] ( $E_{\mathrm{s}}$ method); (2) if the load acting on the top of a pile has been determined, the settlement can be calculated as the deformation of the pile $[28,29]\left(E_{\mathrm{p}}\right.$ method); (3) if the capped piles and foundation soils have been considered to be a whole, a composite module method can be used $[30,31]$ ( $E_{\mathrm{c}}$ method); and (4) if the pile cap and the pile body are regarded as a single pile foundation, the settlement can be calculated using a composite foundation with the settlement-reducing pile method $[32,33]$. In the 
process of settlement, the soil under the pile cap always shares a part of the load [34], and the stress ratio of pile to soil varies with the load level $[35,36]$. Thus, it is difficult to calculate the settlement using $E_{\mathrm{s}}$ or $E_{\mathrm{p}}$ methods in practical project. The composite module method is accurate for flexible pile composite foundations [37] and whether it is suitable for rigid pile composite foundation needs to be verified. In the settlement-reducing piles method, both the average additional pressure at the bottom of cap and the average ultimate frictional resistance at the pile sides are difficult to determine. Currently, the settlement calculation method does not provide any convenient options for capped piles composite foundations, especially rigid piles using PHC or PTC.

In this study, the settlement characteristics and the influencing factors of the capped piles composite foundation were analyzed using finite element software (ABAQUS). Both the capped pile and the soil under the cap were treated as a composite pile within a reinforcement area. Based on this, a convenient settlement calculation method was proposed. Taking a practical embankment reinforced by capped plies composite foundation as an example, the calculated settlement was compared with both that calculated by other methods and field monitoring data to validate this proposed method.

\section{Numerical Analysis of Settlement Characteristics}

Here, the diameter of round cap or side length of square cap is $d$, the pile length is $L$, the pile spacing is $D$, the diameter of pile body is $r$, and the ratio of the cap diameter or side length to the pile diameter is termed as $K$, i.e., $K=d / r$.

2.1. Analysis Model. To study the settlement characteristics of capped piles composite foundation, scenarios involving both capped piles and ordinary piles without caps were $2 \mathrm{D}$ numerically modeled using ABAQUS software of the finite element method. On the contact plane between pile and soil, the deformation is large and the stress concentration is easy to occur, so the mesh division of this part is relatively dense. A 6-pile composite foundation model was established for each scenario, as shown in Figure 1.

The model width is three times of the reinforcement area, and the depth is two times of the reinforcement area [38, 39]. The bottom of the model was fixed in $x$ and $y$ directions. The two sides were fixed in the horizontal ( $x$ direction); vertically ( $y$ direction), they were free. The initial stress fields induced by gravity were calculated to determine the contact pressure. A uniform pressure of $120 \mathrm{kPa}$ was applied to the top of the cushion by six steps with an increment of $20 \mathrm{kPa}$ to simulate the multistage loading of the fill during the embankment construction.

A $300 \mathrm{~mm}$ thick gravel cushion was positioned above the piles. The cushion can adjust the load sharing ratio of pile and soil, reduce the load concentration of piles, and make the piles and soils work together. The piles were labelled A-F from left to right, and the soils between piles were numbered 1-5 from left to right. The pile body is made of concrete, the diameter $(r)$ is $500 \mathrm{~mm}$, and the length $(L)$ is $16 \mathrm{~m}$. The pile cap is a prefabricated concrete slab with an edge length of $1000 \mathrm{~mm}$ and a thickness of $300 \mathrm{~mm}$. Piles were arranged in square with an interval of $2 \mathrm{~m}$. The contact pair was set on the contact surface between the pile body and the soil. According to the rigidity of pile and soil, the surface of pile body is defined as the master surface; the surface of soil around the pile body is the slave surface. The normal behavior of contact pair is "Hard" contact, and the tangential behavior of contact pair is "Penalty." The friction coefficient of the contact surfaces between the pile and the soil is 0.24 . Planar 4-node linear reduced integral elements (CPE4R) were used for the pile-soil contact analysis [40, 41]. The nonlinear solver and Newton method are used in the solution. The Mohr-Coulomb material was used for the silty soil, gravel cushion, and the elastic model for the capped piles. The parameters of modeled materials are listed in Table 1.

2.2. Foundation Settlement. Foundation settlement curves of four different conditions are shown in Figure 2.

Figures 2(a) and 2(b) show that the settlement curves of large in the middle and small at ends both in capped pile and ordinary pile composite foundation, and the maximum settlement occurs in the soil between the piles at the center of the composite foundation. The total settlement of capped piles composite foundation is significantly smaller than that of ordinary piles composite foundation, and this phenomenon occurs at both $D=4 r$ and $D=6 r$.

By comparison, it is found that the pile spacing $D$ has an effect on the total settlement; the larger the $D$, the greater the settlement; the cap diameter ratio $K$ also has an effect on the total settlement; with the increase in $K$, the total settlement decreases, but the decrease is not significant.

However, there are some differences in settlement between the two types of composite foundations. At the same location, the settlement of the soil between ordinary piles is much larger than that of capped piles, whereas the settlement of ordinary pile body is a little smaller than that of capped pile body. Because the area of pile cap is larger than that of pile body, the bearing area of capped pile is larger than that of ordinary pile, and the bearing areas of soil between piles are smaller than that of ordinary pile composite foundation at the same pile spacing. The capped pile bears more load than ordinary pile, which leads to a larger settlement. The bearing areas of soil between piles in capped pile composite foundation are smaller than that of ordinary pile composite foundation, which leads to a smaller settlement. This is accounting for the numerical simulation results.

Figure 2(c) shows the relationship of total settlement with $D$ in capped piles composite foundation. With the increase in $D$, the total settlement increases gradually. When $D$ is increased, the compression modulus of reinforced area $E_{\mathrm{sp}}$ is decreased, which leads to a larger settlement. The settlement at the center position is the largest, while the edge position is the smallest. This implies a loading concentration towards the center in foundation. 


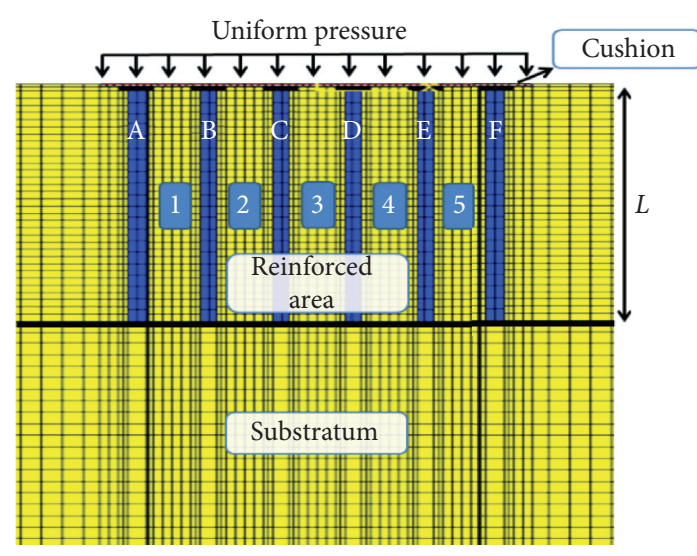

(a)

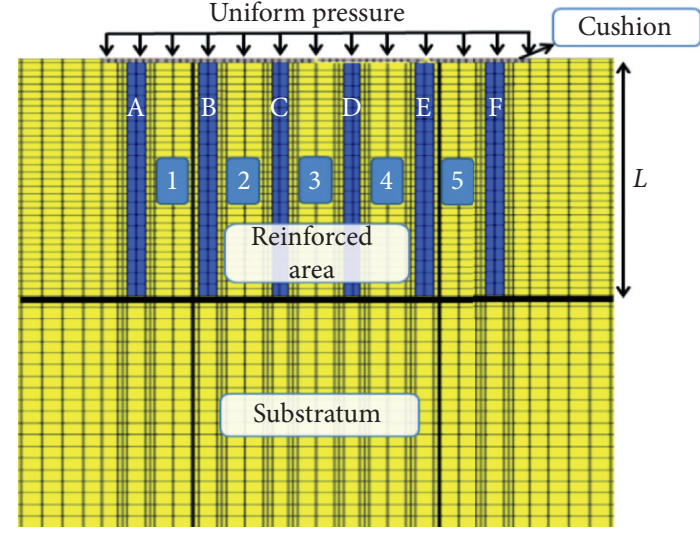

(b)

FIGURE 1: 6-pile composite foundation model for FEM simulation: (a) 6 capped piles; (b) 6 ordinary piles.

TABle 1: Parameters of numerical model materials

\begin{tabular}{|c|c|c|c|c|c|}
\hline Material & Elastic modulus $(\mathrm{kPa})$ & Density $\left(\mathrm{kg} / \mathrm{m}^{3}\right)$ & Cohesion $(\mathrm{kPa})$ & Shearing resistance angle $\left({ }^{\circ}\right)$ & Poisson's ratio \\
\hline Gravel cushion & 64,000 & 2,240 & 0.1 & 40.0 & 0.25 \\
\hline Silty subsoil & 13,000 & 1,980 & 28.0 & 17.8 & 0.30 \\
\hline Concrete capped pile & 3800,000 & 25.0 & - & - & 0.20 \\
\hline
\end{tabular}

Distance from model center $(\mathrm{m})$
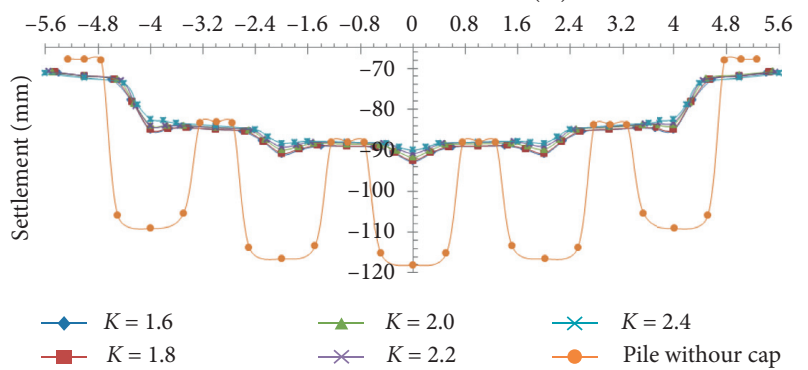

(a)



(c)



(b)

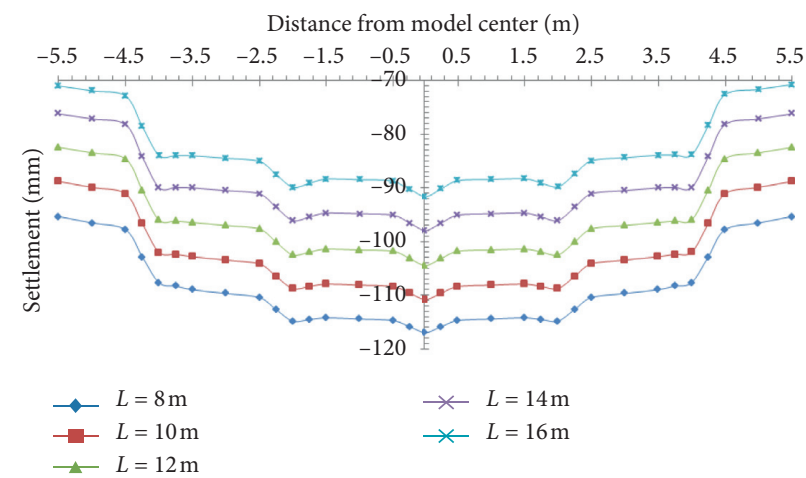

(d)

FIGURE 2: Foundation settlement curves: (a) $D=4 r, L=16 \mathrm{~m}$; (b) $D=6 r, L=16 \mathrm{~m}$; (c) $K=2, L=16 \mathrm{~m}$; (d) $K=2, D=4 r$.

As shown in Figure 2(d), the change in pile length $L$ has an effect on the total settlement. The larger the $L$ is, the smaller the total settlement is. When $L$ is decreased, the reinforced area depth is decreased and the substratum depth is increased (Figure 1), which leads to a larger settlement. 
From Figure 2, the following laws are found: parameters $K, L$, and $D$ affect the total settlement but have different efficiencies. For example, when $K$ changes from 1.6 to 2.4 (1.5 times), the settlement increased $2.8 \mathrm{~mm}$; when $D$ changes from $2 \mathrm{~m}$ to $3 \mathrm{~m}$ (1.5 times), the settlement increased $11.8 \mathrm{~mm}$; when $L$ changes from $8 \mathrm{~m}$ to $12 \mathrm{~m}$ ( 1.5 times), the settlement increased $12.5 \mathrm{~mm}$. It shows that $L$ and $D$ have a greater impact on the total settlement, while $K$ has a smaller one.

2.3. Differential Settlement of Capped Pile and Soil. In order to study the characteristics of differential settlement of capped pile and soil in the composite foundation, the location of soil between piles (Figure 1) is taken as the specific reference position. The curves of pile-soil differential settlement are shown in Figure 3.

Figures 3(a) and 3(b) show that the differential settlement of capped piles composite foundation is significantly smaller than that of ordinary foundation, and this phenomenon occurs both at $D=4 r$ and $D=6 r$. Taking the middle position as the reference point in Figure 3(a), the differential settlement is only $6.1 \mathrm{~mm}$ for capped piles, while it is $26.5 \mathrm{~mm}$ for ordinary piles. This implies that the pile-soil differential settlement can be effectively reduced by installing suitable caps on pile tops.

Besides, with the increase in $K$, the differential settlement decreases, and $K$ affects the differential settlement greatly. Taking Figure 3(b) for example, the central differential settlement is $15.6 \mathrm{~mm}$ when $K=2$, while it is $9.0 \mathrm{~mm}$ when $K=3$.

Furthermore, the effect of $K$ on differential settlement is related to $D$. In Figure 3(a), in middle position, the differential settlement is $3.2 \mathrm{~mm}$ for $K=2$ and $D=2 \mathrm{~m}$, while it is $15.6 \mathrm{~mm}$ for $K=2$ and $D=3 \mathrm{~m}$ in Figure 3(b).

Figures 3(c) and 3(d) show the influence of $D$ and $L$ on the differential settlement, respectively. In Figure 3(c), the differential settlement increased with increasing $D$. When $D$ changes from $2 \mathrm{~m}$ to $3 \mathrm{~m}$, the central differential settlement increased $9.6 \mathrm{~mm}$. In Figure 3(d), the differential settlement decreased with increasing $L$. When $L$ changes from $8 \mathrm{~m}$ to $12 \mathrm{~m}$, the central differential settlement decreased $0.4 \mathrm{~mm}$. This indicates that $D$ impacts the pile-soil differential settlement greatly, while $L$ has minor influence which can be ignored.

To summarize, the settlement of capped piles composite foundation has following main characteristics: (1) the total settlement is much smaller than ordinary composite foundation; (2) the pile-soil differential settlement is much smaller than ordinary composite foundation; (3) $D$ and $L$ affect the overall settlement greatly; and (4) $K$ and $D$ affect the pile-soil differential settlement greatly.

It is found from documents above that, in practical applications, the value of $K$ is usually designed within $2 \sim 3, D$ within $4 r \sim 6 r$, and the cap thickness is $200 \mathrm{~mm} \sim 500 \mathrm{~mm}$. In view of above, the differential settlement of capped piles composite foundation is very similar to that of flexible piles [42] and compressible piles composite foundations [43], as shown in Figure 4.
For flexible pile and compressible pile composite foundation, the composite modulus method is widely used in settlement calculation [31, 44]. So, a similar calculation method is proposed below.

\section{Proposed Calculation Method for Settlement}

3.1. Settlement Calculation Model. The capped piles composite foundation consists of cushion, reinforcement area, and substratum. Cushion is an important part of composite foundation, which gives full play to the bearing capacity of soil and improves the bearing conditions of piles in composite foundation.

Based on the settlement characteristics of capped piles composite foundation, the following assumptions are adopted: (1) the capped pile and the soil under the cap bear the load and settled together, and they are assumed to be a composite pile, as shown in Figure 5; (2) the pile-soil differential settlement is ignored in the reinforced area; (3) the physical and mechanical properties and the thickness of a single soil layer are isotropic and evenly distributed; and (4) the additional stress in the foundation is calculated using the Boussinesq solution [45].

Then, the conceptual model of composite pile is established, as illustrated in Figure 5.

3.2. Calculation Method. Capped piles are used to increase the ability of soft soil foundation to resist deformation and reduce settlement. Based on the concept of composite pile, the settlement calculation model of capped piles composite foundation is illustrated in Figure 6.

In Figure 6, the total settlement $(s)$ consists of three parts: the cushion settlement $\left(s_{\mathrm{c}}\right)$, the reinforced area settlement $\left(s_{1}\right)$, and the underlying stratum settlement $\left(s_{2}\right)$. Considering that the settlement of cushion $s_{\mathrm{c}}$ had been largely completed during the construction, it is ignored in this settlement calculation. Then, the total settlement can be calculated by

$$
\begin{gathered}
s=s_{1}+s_{2}, \\
s_{1}=\psi_{s 1} \sum_{i=1}^{n} \frac{\Delta p_{i}}{E_{\mathrm{spi}}} l_{i}, \\
s_{2}=\psi_{s 2} \sum_{i=1}^{n} \frac{\Delta p_{i}}{E_{\mathrm{si}}} l_{i} .
\end{gathered}
$$

According to assumption (2), $E_{\mathrm{sp}}$ is calculated as follows:

$$
E_{\mathrm{spi}}=m E_{\mathrm{p}}+(1-m) E_{\mathrm{si}} \text {. }
$$

Here, $m$ is the area replacement rate of capped piles composite foundation and is calculated according to the cap area. When capped piles are arranged in equilateral triangles (Figure 7(a)),

$$
m=\frac{A_{\mathrm{c}}}{A}=\frac{2 \sqrt{3} A_{\mathrm{c}}}{3 D^{2}}
$$

When capped piles are arranged in squares (Figure 7(b)), 


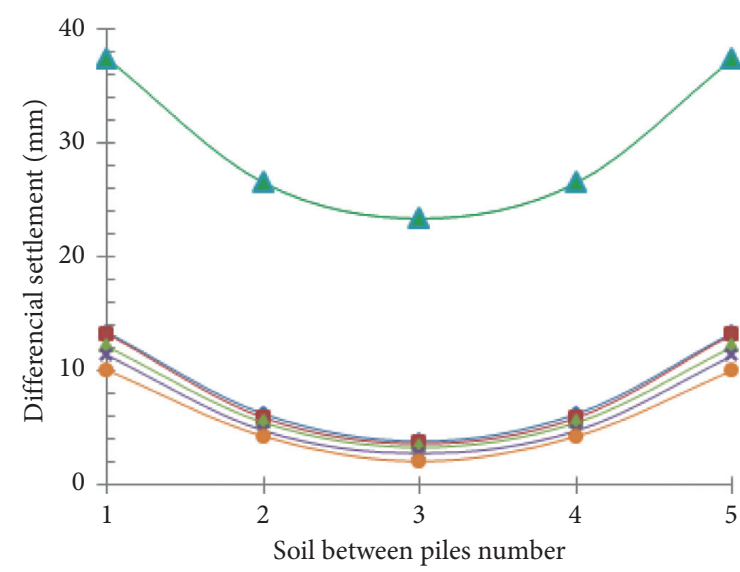

Soil between piles number
- Without cap
$\rightarrow K=1.8$
$\leftarrow K=2.2$
$\multimap K=1.6$
$\triangle K=2$
$\longrightarrow K=2.4$

(a)

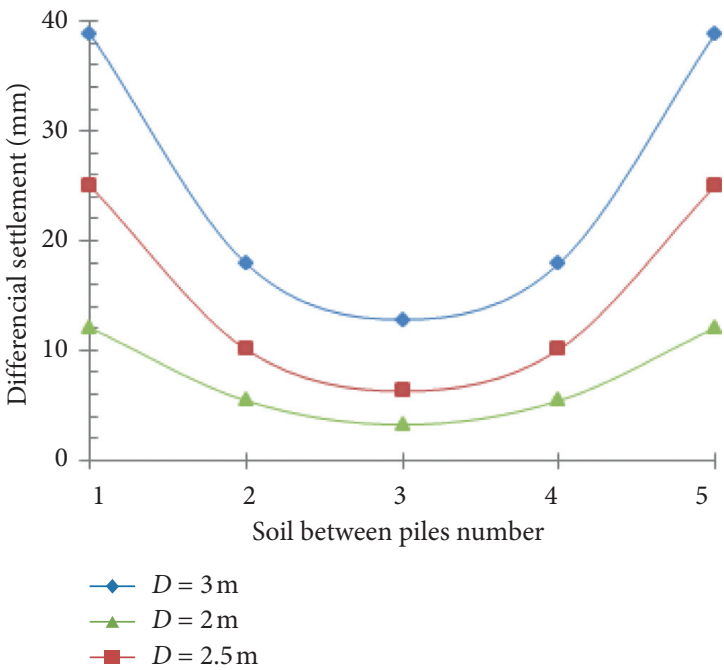

(c)

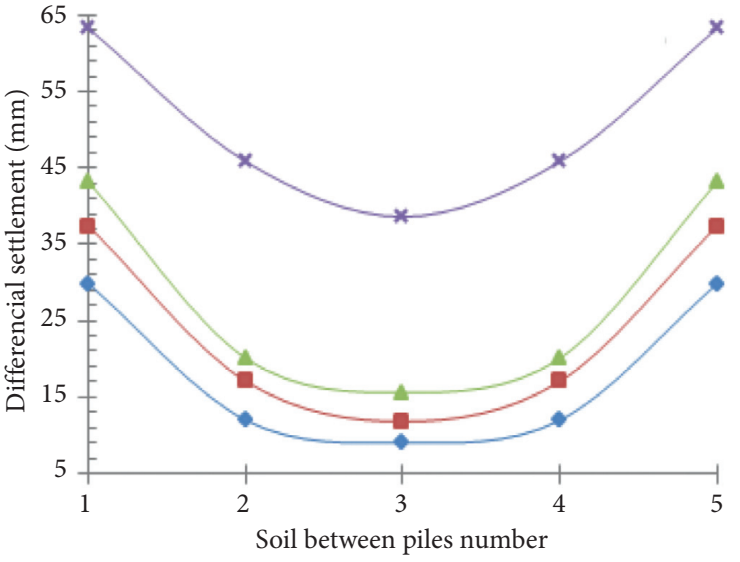

$$
\begin{array}{ll}
\rightarrow K=3 & \rightarrow K=2.4 \\
\rightarrow K=2 & \rightarrow \text { Without cap }
\end{array}
$$

(b)

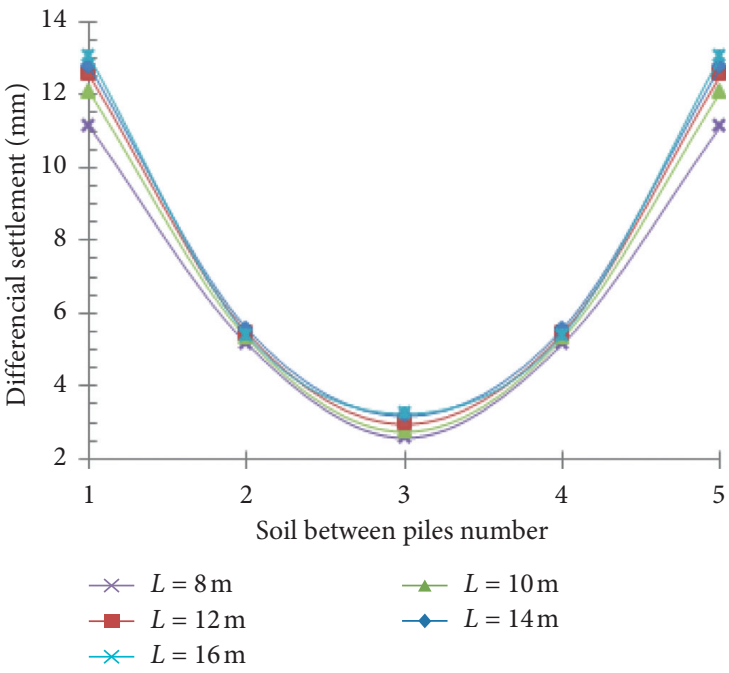

(d)

Figure 3: Curve of pile-soil differential settlement: (a) $D=2 \mathrm{~m}, L=16 \mathrm{~m}$; (b) $D=3 \mathrm{~m}, L=16 \mathrm{~m}$; (c) $K=2, L=16 \mathrm{~m}$; (d) $K=2, D=2 \mathrm{~m}$.



FIgURE 4: Comparison of pile-soil differential settlement in center position. 




FIgURE 5: Conceptual model of composite pile.

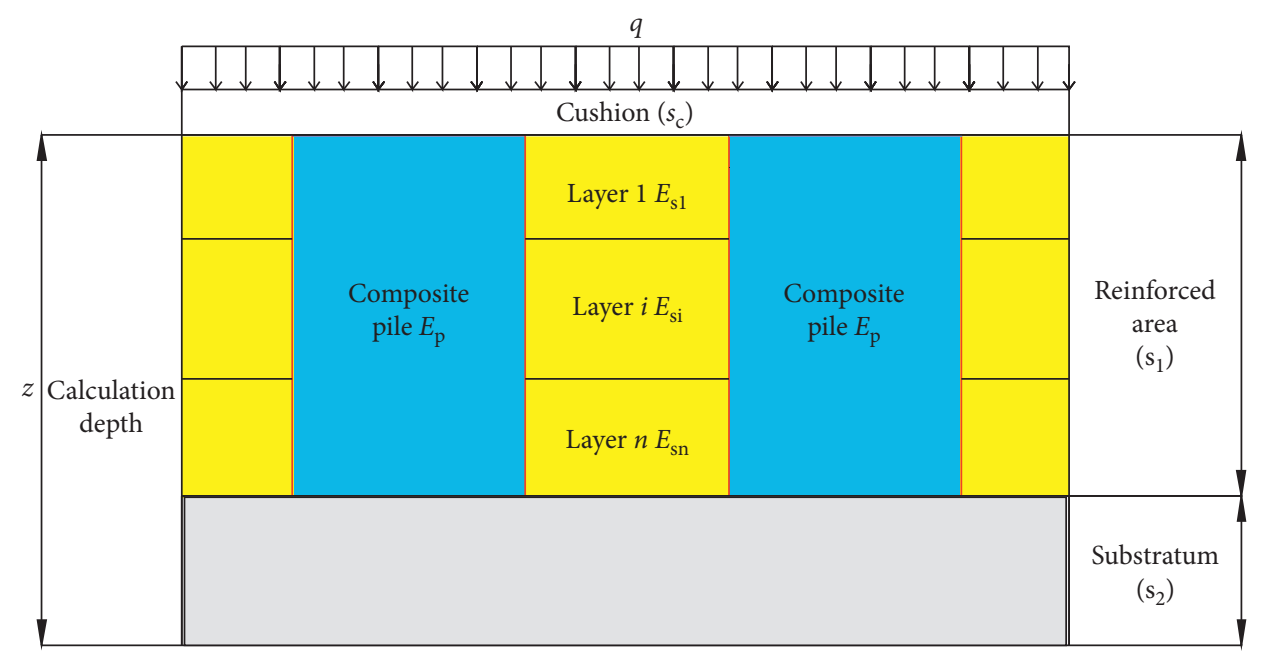

FIGURE 6: Settlement calculation model of capped piles composite foundation.

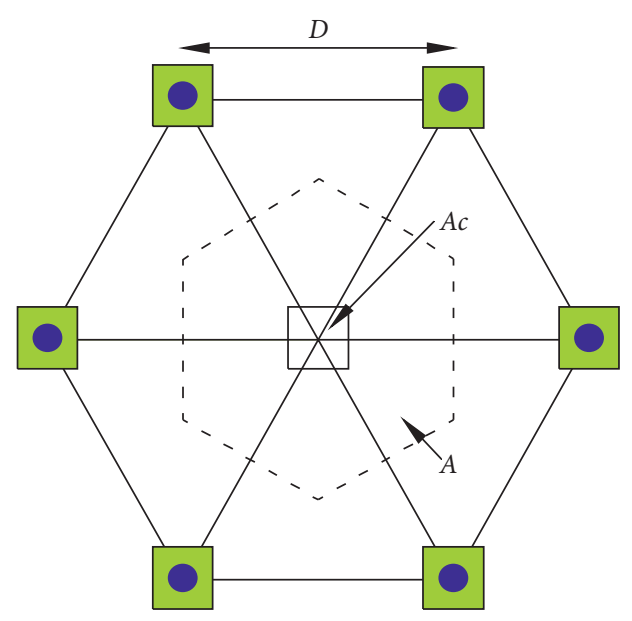

(a)

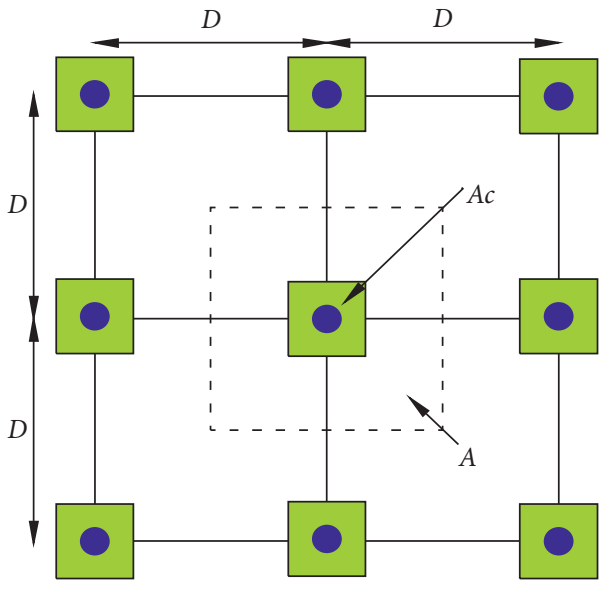

(b)

FIGURE 7: Layout of piles arrangement: (a) equilateral triangle arrangement; (b) square arrangement. 


$$
m=\frac{A_{\mathrm{c}}}{A}=\frac{A_{\mathrm{c}}}{D^{2}}
$$

The compressive modulus of the composite pile $\left(E_{\mathrm{p}}\right)$ reflects the integrated deformability of the pile and the soil under load and is affected by many factors such as pile diameter, pile side friction, pile tip resistance, soil properties, and cap size. Thus, it is not easy to be determined by means of laboratory tests, such as $E_{s}$. Therefore, it is necessary to find an equivalent way to find out $E_{\mathrm{p}}$.

Research studies in this area showed that when using pile deformation modulus instead of pile compression modulus, the calculated settlement of composite foundation is closer to the measured result [46, 47]. This method is adopted in the following calculation. In engineering practice, the pile deformation modulus can be obtained by the load-settlement curve with a certain calculation mode, and the following elastic theoretical formula is used [48]:

$$
E_{\mathrm{p}}=\alpha \times\left(1-v^{2}\right) \times B \times k,
$$

where $k$ is the secant slope on the load-settlement curve, $B$ is the side length or diameter of the loading plate, and $\alpha$ is the settlement influence coefficient. When the circular loading plate is used, $\alpha$ is $\pi / 4$; when the square loading plate is used, $\alpha$ is $\sqrt{\pi} / 2$.

This field static load test method can comprehensively respond to the influences of soil characteristics, pile diameter, pile length, cap size, and other factors; hence, it is strongly representative. Actually, the load-settlement curve is a nonlinear curve in soft soil areas, and $k$ is varied with the ratio of load to settlement. However, the static load test is destructive, and the ultimate load is often much higher than the designed embankment load. For example, in a load test, the value of ultimate pressure of a capped pile is nearly $3000 \mathrm{kPa}$, whereas the value of actual pressure caused by subgrade fill is only $180 \sim 250 \mathrm{kPa}$ [2]. The settlement caused by actual designed embankment pressure is typically located in the initial position of the final load-settlement curve. So, the $k$ is suggested to be calculated at the design load point on the load-settlement curve. If there is a linear part in the initial section of the load-settlement curve, $k$ can also be calculated according to the slope of the linear section.

3.3. Calculation Procedure. The settlement calculation procedure was carried out in the following sequence:

(1) Calculate the additional stress increment $(\Delta p)$ caused by embankment using the Boussinesq solution: soil properties such as $E_{\mathrm{s}}$ are determined by field or laboratory investigations. The calculation depth $(z)$ is determined as the depth where the additional stress is 0.1 times the gravity stress [49].

(2) Calculate the compressive modulus of the reinforced area $\left(E_{\mathrm{sp}}\right)$ : pile length and other dimension parameters are obtained from the design scheme. According to the pile layout, the area replacement rate $m$ is calculated using equations (5a) or (5b). The compressive modulus $\left(E_{\mathrm{p}}\right)$ is yielded through equation (6), according to the field static load test. By substituting the values of $m$ and
$E_{\mathrm{p}}$ into equation (4), the compressive modulus of the reinforced area $\left(E_{\mathrm{sp}}\right)$ is obtained.

(3) Calculate the total settlement of the capped piles composite foundation $(s)$ : when $E_{\mathrm{s}}, m$, and $E_{\mathrm{sp}}$ have been determined, the settlement of the composite foundation can be calculated using equations (1)-(3).

\section{Verification and Comparison}

A highway renovation is located in Bohai Bay, Hebei Province, China. A cross-line bridge has been constructed with a filling height of $6 \mathrm{~m}$ behind an abutment. The distribution and parameters of the soil layers under the embankment are shown in Table 2.

The new pavement is $18 \mathrm{~m}$ wide, the soft soils under embankment were treated using a capped piles composite foundation. Figure 8 shows the field photographs of the foundation treatment.

The pile bodies were C80 prestressed concrete pipe piles with an external diameter of $500 \mathrm{~mm}$, an inner diameter of $380 \mathrm{~mm}$, and a length of $16 \mathrm{~m}$. Pile cap was a prefabricated concrete square with an edge length of $1000 \mathrm{~mm}$ and a thickness of $250 \mathrm{~mm}$. The capped piles were set in an equilateral triangle formation with a side length of $2.2 \mathrm{~m}$. The schematic diagram of the pile arrangement is shown in Figure 9.

It should be pointed out that the hollow pipe piles were used in this project, and their deformation modulus is different from that of solid piles with equal diameter because the actual compressive cross-sectional area is different. However, when using equation (6) for $E_{\mathrm{p}}$ calculation, the cross-sectional difference is negligible.

The area replacement rate $m$ is calculated using the pile caps area, where $m=0.238$; the calculation depth $z=26 \mathrm{~m}$, and the calculation thickness of each layer is $2 \mathrm{~m}$. The in situ load-settlement curve of single capped pile is shown in Figure 10. The slope of secant line $\mathrm{AB}(k)$ is 150.4 ; the deformation modulus $E_{\mathrm{p}}$ of the composite pile is $169.8 \mathrm{MPa}$ $(B=1.4, \quad \alpha=\sqrt{\pi} / 2)$, according to equation (6). Finally, equations (1)-(3) were used to calculate the total settlement $\left(\psi_{\mathrm{s} 1}=\psi_{\mathrm{s} 2}=1.0\right)$. The calculation parameters and results are shown in Table 3.

In Table 3, the calculated total settlement was $85.99 \mathrm{~mm}$; this met the designed requirement of $100 \mathrm{~mm}$. The settlement of the reinforced area was $30.0 \mathrm{~mm}$ and that of the substratum was $56.0 \mathrm{~mm}$. This shows that the settlement of the substratum accounted for the majority of the total settlement.

The observed settlements with elapsed time at $\mathrm{P}_{1}$ and $\mathrm{P}_{2}$ are shown in Figure 11.

Calculated and observed settlements are compared in Table 4.

Error analysis indicates that the result calculated by the proposed method has a minimum error of $10.8 \%$ which is substantially less than the estimates obtained by the $E_{\mathrm{p}}$ method (23.4\%), the settlement-reducing piles method $(42.9 \%)$, and the $E_{\mathrm{c}}$ method $(88.1 \%)$. Consequently, the proposed method is in good agreement with the observed data and is convenient for calculating the settlement of capped piles composite foundation under embankment load. 
TABLE 2: Distribution and parameters of soil layer [50].

\begin{tabular}{|c|c|c|c|c|c|c|}
\hline Layer & Thickness (m) & Gravity density $\left(\mathrm{kN} / \mathrm{m}^{3}\right)$ & Modulus (MPa) & Cohesion $(\mathrm{kPa})$ & Internal friction angle $\left({ }^{\circ}\right)$ & Poisson's ratio \\
\hline Gravel cushion & 0.25 & 22.4 & 64000 & 0.1 & 40 & 0.25 \\
\hline Fill & 2 & 18.1 & 2.84 & 20.0 & 30 & 0.25 \\
\hline Silt & 4 & 18.3 & 5.20 & 15.2 & 17 & 0.30 \\
\hline Silt & 2 & 18.2 & 5.13 & 14.9 & 18 & 0.30 \\
\hline Silty clay & 8 & 19.6 & 4.95 & 13.7 & 21 & 0.28 \\
\hline Silty clay & 16 & 19.7 & 9.15 & 20.2 & 25 & 0.25 \\
\hline
\end{tabular}

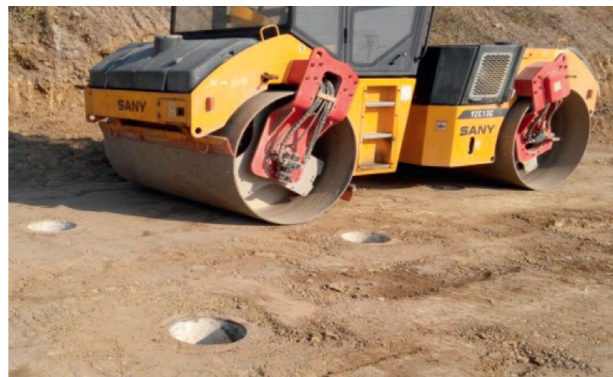

(a)

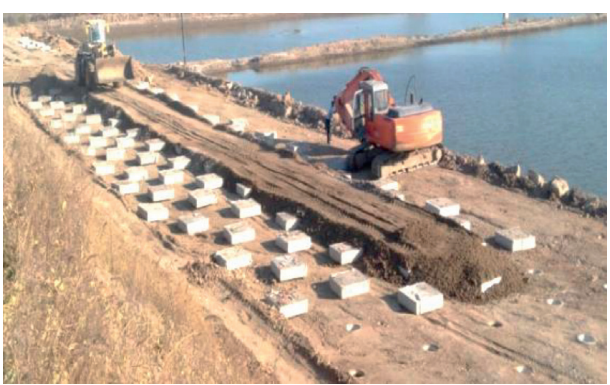

(b)

FIGURE 8: Field photographs of foundation treatment: (a) before installing caps; (b) after installing caps.

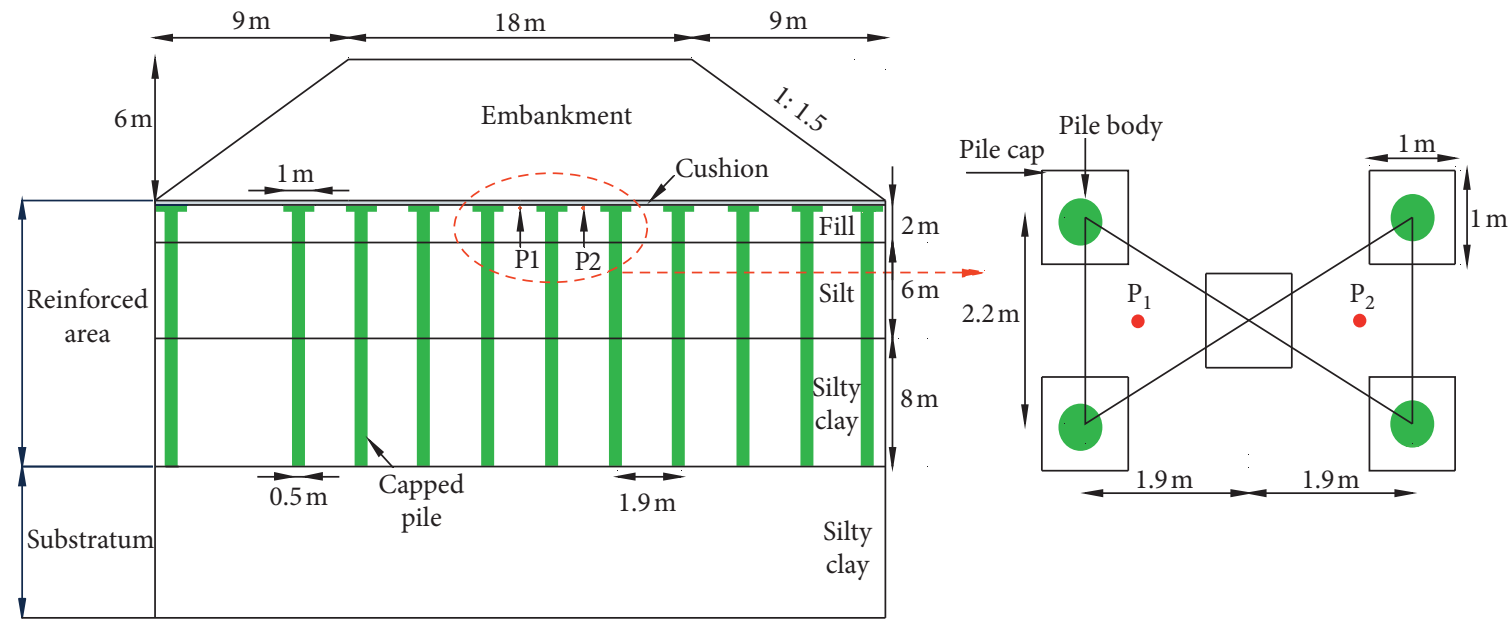

Figure 9: Schematic diagram of pile arrangement: settlement observation points $\left(\mathrm{P}_{1}\right.$ and $\left.\mathrm{P}_{2}\right)$.



Figure 10: Load-settlement curve of single capped pile. 
TABLE 3: Computation parameters and results.

\begin{tabular}{|c|c|c|c|c|c|c|c|}
\hline Location & Layer & Soil & $E_{\mathrm{s}}(\mathrm{MPa})$ & Thickness (m) & $E_{\mathrm{p}}(\mathrm{MPa})$ & $E_{\mathrm{sp}}(\mathrm{MPa})$ & Settlement $(\mathrm{mm})$ \\
\hline \multirow{8}{*}{ Reinforced area } & 1 & Fill & 2.84 & 2 & 169.8 & 42.58 & 6.45 \\
\hline & 2 & Silt & 5.20 & 2 & 169.8 & 44.37 & 5.37 \\
\hline & 3 & Silt & 5.20 & 2 & 169.8 & 44.37 & 4.49 \\
\hline & 4 & Silt & 5.13 & 2 & 169.8 & 44.32 & 3.69 \\
\hline & 5 & Silty clay & 4.95 & 2 & 169.8 & 44.18 & 3.11 \\
\hline & 6 & Silty clay & 4.95 & 2 & 169.8 & 44.18 & 2.64 \\
\hline & 7 & Silty clay & 4.95 & 2 & 169.8 & 44.18 & 2.27 \\
\hline & 8 & Silty clay & 4.95 & 2 & 169.8 & 44.18 & 2.00 \\
\hline \multirow{5}{*}{ Substratum } & 9 & Silty clay & 9.15 & 2 & - & - & 13.55 \\
\hline & 10 & Silty clay & 9.15 & 2 & - & - & 12.14 \\
\hline & 11 & Silty clay & 9.15 & 2 & - & - & 10.99 \\
\hline & 12 & Silty clay & 9.15 & 2 & - & - & 10.14 \\
\hline & 13 & Silty clay & 9.15 & 2 & - & - & 9.15 \\
\hline Total settlement $(\mathrm{mm})$ & & & & & & & 85.99 \\
\hline
\end{tabular}

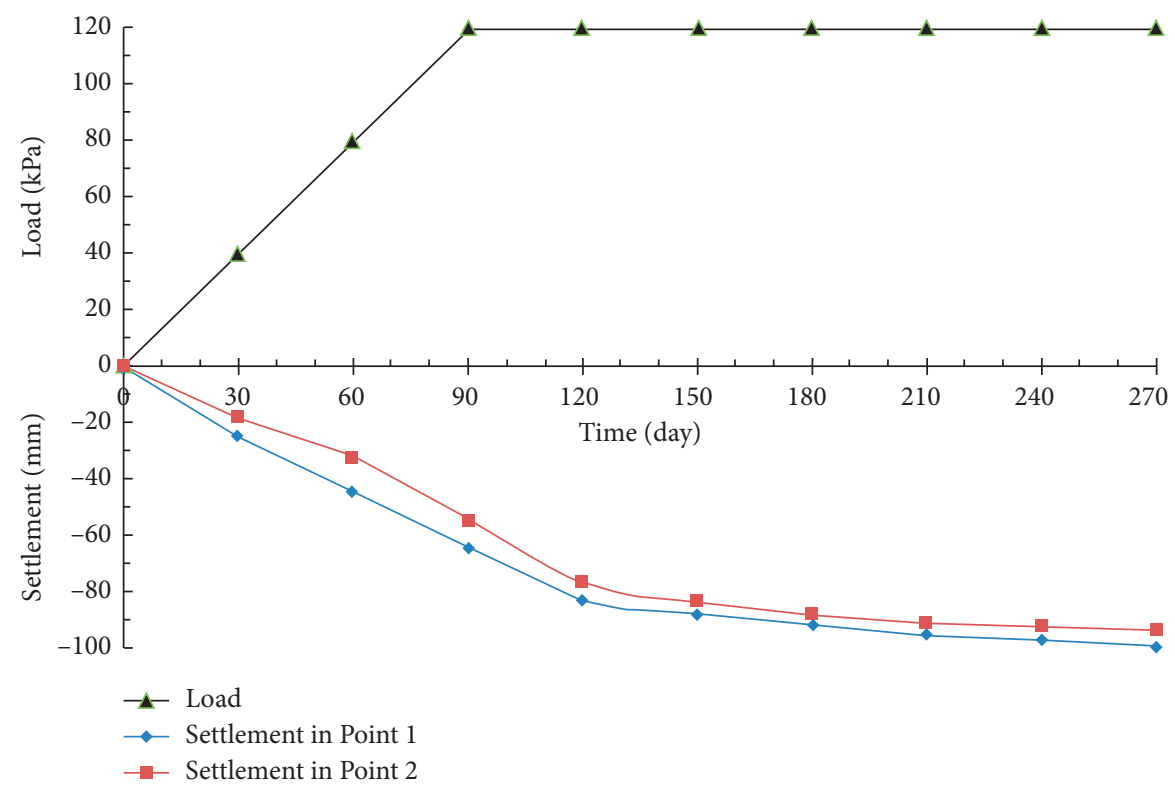

Figure 11: Observed settlements with elapsed time at $\mathrm{P}_{1}$ and $\mathrm{P}_{2}$.

TABLE 4: Settlement comparison of calculated and observed results.

\begin{tabular}{lccccc}
\hline Calculation method & This method & $E_{\mathrm{s}}$ method [21] & $E_{\mathrm{p}}$ method [22] & Settlement-reducing piles method [27] & Observed data \\
\hline Settlement $(\mathrm{mm})$ & 86.0 & 181.3 & 73.8 & 137.8 & $98.7\left(\mathrm{P}_{1}\right)$ \\
\hline Error $(\%)$ & 10.8 & 88.1 & 23.4 & 42.9 & $94.1\left(\mathrm{P}_{2}\right)$ \\
\hline
\end{tabular}

\section{Conclusions}

This paper focused on the settlement characteristics and the settlement calculation of capped piles composite foundation based on numerical and theoretical analysis. The key conclusions were summarized as follows:

(1) The pile spacing and pile length are the main factors to the total settlement of the capped piles composite foundation, while the pile spacing and the ratio of pile cap to pile diameter are the main factors accounting for the pile-soil differential settlement, and the differential settlement of capped piles composite foundation is very similar to that of flexible pile and compressible pile composite foundations.

(2) Based on the numerical results, a theoretical formula for calculating the total settlement of the capped piles 
composite foundation using the layer-wise summation method is proposed. And a real embankment engineering with capped piles composite foundation is adopted to validate this method; by comparing with other methods, the results show that the proposed method is the most consistent with the field monitoring data. As long as the load-settlement curve of single capped pile can be obtained in site or be simulated out, the total settlement of composite foundation can be predicted by this method, which provides a great convenience for scheme design and optimal design.

\section{Data Availability}

All data, models, and code generated or used during the study are included within the article.

\section{Conflicts of Interest}

The authors declare that they have no conflicts of interest.

\section{Acknowledgments}

This work was supported by the National Natural Science Foundation of China (nos. 41672300 and 41807279) and the Supporting Program of Hundred Promising Innovative Talents in Hebei Provincial Education Office (no. SLRC2019027). The financial supports are gratefully acknowledged.

\section{References}

[1] MOHURD (Ministry of Housing and Urban-Rural Development of the People's Republic of China), Technical Code for Composite Foundation, China planning Press, Beijing, China, 2012.

[2] J. B. Lei and C. Q. Chen, "Research on load transfer mechanism of composite foundation of rigid pile with cap based on hyperbolic model," Rock and Soil Mechanics, vol. 31, no. 11, pp. 3385-3391, 2010.

[3] S. W. Abusharar, J.-J. Zheng, B.-G. Chen, and J.-H. Yin, “A simplified method for analysis of a piled embankment reinforced with geosynthetics," Geotextiles and Geomembranes, vol. 27 , no. 1, pp. 39-52, 2009.

[4] W. P. Hong and S. Hong, "Piled embankment to prevent damage to pipe buried in soft grounds undergoing lateral flow," Marine Georesources \& Geotechnology, vol. 35, no. 5, pp. 719-729, 2016.

[5] B. P. Doanh, Q. Luo, L. Zhang, and Y. Yang, "Geotechnical centrifuge experiment and force analysis of reinforced cushion with pile cap net structure embankment," in Proceedings of the 4th Asian Regional Conference on Geosynthetics, pp. 185-190, Shanghai, China, 2008.

[6] A. T. Ghalesari, A. Barari, P. F. Amini, and L. B. Ibsen, "The settlement behavior of piled raft interaction in undrained soil," in Proceedings of the IACGE 2013, Chengdu, China, October 2013.

[7] M. Y. Fattah, M. A. Al-Obaydi, and F. A. Al-Jalabi, "Effect of number of piles on load sharing in piled raft foundation system in saturated gypseous soil," International Journal of
Civil Engineering and Technology (IJCIET), vol. 9, no. 3, pp. 932-944, 2018.

[8] L. Briançon and B. Simon, "Pile-supported embankment over soft soil for a high-speed line," Geosynthetics International, pp. 1-13, 2017.

[9] S.-L. Luo, X.-G. Jin, and D. Huang, "Long-term coupled effects of hydrological factors on kinematic responses of a reactivated landslide in the Three Gorges Reservoir," Engineering Geology, vol. 261, Article ID 105271, 2019.

[10] S. Rezaeimalek, A. Nasouri, J. Huang, S. Bin-Shafique, S. T. fiGilazghi, and S. T. Gilazghi, "Comparison of short-term and long-term performances for polymer-stabilized sand and clay," Journal of Traffic and Transportation Engineering, vol. 4, no. 2, pp. 145-155, 2017.

[11] M. A. Nunez, L. Briançon, and D. Dias, "Analyses of a pilesupported embankment over soft clay: full-scale experiment, analytical and numerical approaches," Engineering Geology, vol. 153, pp. 53-67, 2013.

[12] A. Taghavi Ghalesari, A. Barari, P. Fardad Amini, and L. B. Ibsen, "Development of optimum design from static response of pile-raft interaction," Journal of Marine Science and Technology, vol. 20, no. 2, pp. 331-343, 2014.

[13] D. Dia and J. Grippon, "Numerical modelling of a pilesupported embankment using variable inertia piles," Structural Engineering and Mechanics, vol. 61, no. 2, pp. 245-253, 2017.

[14] M. Y. Fattah, M. A. Yousif, and S. M. Al-Tameemi, "Bearing capacity of pile group and piled raft foundations on sandy soil," Journal of Engineering and Development, vol. 17, no. 2, pp. 64-96, 2013.

[15] A. T. Ghalesari and H. Rasouli, "Effect of gravel layer on the behavior of piled raft foundations," Advances in Soil Dynamics and Foundation Engineering, pp. 373-382, 2014.

[16] Z. Zhong, D. Huang, Y. Zhang, and G. Ma, "Experimental study on the effects of unloading normal stress on shear mechanical behaviour of sandstone containing a parallel fissure pair," Rock Mechanics and Rock Engineering, vol. 53, no. 4, pp. 1647-1663, 2020.

[17] W. Z. Liu, J. H. Zhang, and H. Zhang, "Analysis on pile-soil stress ratio of composite foundation with sparse capped-piles under lime-soil embankment load," Applied Mechanics and Materials, vol. 501-504, pp. 124-131, 2014.

[18] L. Briançon and B. Simon, "Performance of pile-supported embankment over soft soil: full-scale experiment," Journal of Geotechnical and Geoenvironmental Engineering, vol. 138, no. 4, pp. 551-561, 2012.

[19] M. J. Al-Mosawe, M. Y. Fattah, and A. A. O. Al-Zayadi, "Experimental observations on the behavior of a piled raft foundation," Journal of Engineering, College of Engineering, University of Baghdad, vol. 17, no. 4, pp. 807-828, 2011.

[20] M. Modarresi, H. Rasouli, A. T. Ghalesari, and M. H. Baziar, "Experimental and numerical study of pile-to-pile interaction factor in sandy soil," Procedia Engineering, vol. 161, pp. 1030-1036, 2016.

[21] B. Le Hello and P. Villard, "Embankments reinforced by piles and geosynthetics-numerical and experimental studies dealing with the transfer of load on the soil embankment," Engineering Geology, vol. 106, no. 1-2, pp. 78-91, 2009.

[22] R. K. Rowe and K.-W. Liu, "Three-dimensional finite element modelling of a full-scale geosynthetic-reinforced, pile-supported embankment," Canadian Geotechnical Journal, vol. 52, no. 12, pp. 2041-2054, 2015.

[23] X. Tan, M. Zhao, and W. Chen, "Numerical simulation of a single stone column in soft clay using the discrete-element 
method," International Journal of Geomechanics, vol. 18, no. 12, Article ID 04018176, 2018.

[24] Q. Fu, H.-l. Liu, X.-m. Ding, and C.-j. Zheng, "Numerical investigation of piled raft foundation in mitigating embankment vibrations induced by high-speed trains," Journal of Central South University, vol. 22, no. 11, pp. 4434-4444, 2015.

[25] A. Taghavi Ghalesari and A. Janalizadeh Choobbasti, "Numerical analysis of settlement and bearing behaviour of piled raft in Babol clay," European Journal of Environmental and Civil Engineering, vol. 22, no. 8, pp. 978-1003, 2016.

[26] M. Y. Fattah, M. J. Al-Mosawi, and A. A. O. Al-Zayadi, "Time dependent behavior of piled raft foundation in clayey soil," Geomechanics and Engineering, vol. 5, no. 1, pp. 17-36, 2013.

[27] B. G. Rao and G. Ranjan, "Settlement analysis of skirted granular piles," Journal of Geotechnical Engineering, vol. 111, no. 11, pp. 1264-1283, 1985.

[28] V. Singh and S. K. Lal, "Analytical method for settlement of axially loaded compressible pile," Indian Geotechnical Journal, vol. 42, no. 2, pp. 75-86, 2012.

[29] J. F. Liu, G. Zheng, and X. N. Gong, "Superimposed stress method to calculate settlement of embankment with rigid-pile composite foundation," Chinese Journal of Geotechnical Engineering, vol. 40, no. 11, pp. 1995-2002, 2018.

[30] X. S. Cheng and W. Jing, "Calculation models and stability of composite foundation treated with compaction piles," Geomechanics and Engineering, vol. 13, no. 6, pp. 929-946, 2017.

[31] Z.-F. Wang, W.-C. Cheng, Y.-Q. Wang, and J.-Q. Du, "Simple method to predict settlement of composite foundation under embankment," International Journal of Geomechanics, vol. 18, no. 12, Article ID 04018158, 2018.

[32] J. P. Love, "Use of settlement reducing piles to support a raft structure," Proceedings of the Institution of Civil Engineers-Geotechnical Engineering, vol. 156, no. 4, pp. 177-181, 2003.

[33] P. D. Long, "Prediction of piled raft foundation settlement-a case study," Geotechnical Engineering, vol. 47, no. 1, pp. 1-6, 2016.

[34] M. Y. Fattah, M. A. Yousif, and S. M. K. Al-Tameemi, "Effect of pile group geometry on bearing capacity of piled raft foundations," Structural Engineering and Mechanics, vol. 54, no. 5, pp. 829-853, 2015.

[35] Y. K. Chow, A. S. C. E. Member, and C. I. The, "Pile-cap-pilegroup interaction in nonhomogen- eous soil," International Journal of Rock Mechanics and Mining Sciences \& Geomechanics, vol. 29, no. 3, p. A184, 1992.

[36] S. Tamura and T. Hida, "Pile stress estimation based on seismic deformation method with embedment effects on pile caps," Journal of Geotechnical and Geoenvironmental Engineering, vol. 140, no. 9, Article ID 04014049, 2014.

[37] J. J. Zheng, Y. Liu, Y. T. Pan, and J. Hu, "Statistical evaluation of the load-settlement response of a multicolumn composite foundation," International Journal of Geomechanics, vol. 18, no. 4, Article ID 04018015, 2018.

[38] S. W. Abusharar, J.-J. Zheng, and B.-G. Chen, "Finite element modeling of the consolidation behavior of multi-column supported road embankment," Computers and Geotechnics, vol. 36, no. 4, pp. 676-685, 2009.

[39] F. Zhou, J. Xu, and X. Wang, "Finite layer formulations for land subsidence due to groundwater withdrawal," International Journal of Geomechanics, vol. 17, no. 11, Article ID 04017099, 2017.

[40] R. Ragni, B. Bienen, D. Wang, D. Mašín, and M. J. Cassidy, "Numerical modelling of the effects of consolidation on the undrained spudcan capacity under combined loading in silty clay," Computers and Geotechnics, vol. 86, pp. 33-51, 2017.

[41] J. Zhang, X. Cui, D. Huang, Q. Jin, J. Lou, and W. Tang, "Numerical simulation of consolidation settlement of pervious concrete pile composite foundation under road embankment," International Journal of Geomechanics, vol. 16, no. 1, Article ID B4015006, 2016.

[42] S. Li, X. Huang, and C. Zeng, "Performance of an embankment foundation with sand over clay: experimental and numerical analyses," International Journal of Geomechanics, vol. 17, no. 6, Article ID 06016038, 2017.

[43] J. He, K. N. Zhang, J. Liu, Y. P. Wu, and B. Li, "Bearing behavior of column-soil-cushion mutual action in composite foundation with rammed cement-soil column," Journal of Central South University (Science and Technology), vol. 43, no. 6, pp. 2288-2294, 2012.

[44] S. G. Wang, Z. L. zhang, and Y. L. Yuan, "The calculation method Combined with Mindlin's solution and Boussinesq's analytical solutions to calculate composite foundation settlement," Xi'an University of Architecture and Technology, vol. 50, no. 6, pp. 820-825, 2018.

[45] J. Boussinesq, Application des Potentiels a L'etude de L'equilibre et du Mouvement des Solides Elastiques, GauthierVillars, Paris, France, 1885.

[46] G. H. Yang, J. Li, K. Jia, and Z. K. Li, "Improved settlement calculation method for engineering practice," Chinese Journal of Rock Mechanics and Engineering, vol. 36, no. S2, pp. 4229-4234, 2017.

[47] M. L. Yan, X. L. Qu, W. Liu, X. Z. Meng, and X. H. Yan, "Composite modulus analysis of composite foundation," Building Science, vol. 20, no. 4, pp. 27-32, 2004.

[48] D. Zhang, "Analysis and computation of the deformation modulus of the pile in the composite foundation," Chinese Journal of Rock Mechanics and Engineering, vol. 21, no. 2, pp. 70-73, 1999.

[49] J. D. Geddes, "Stresses in foundation soils due to vertical subsurface loading," Géotechnique, vol. 16, no. 3, pp. 231-255, 1966.

[50] M. Q. Liu, C. Y. Liu, and X. Z. Li, "Settlement calculation method of rivet pile composite foundation under embankment load," Acta Technica CSAV, vol. 62, no. 2B, pp. 743-752, 2017. 